\title{
Evaluation of a Bioabsorbable Self-Expandable Vein Stent-Base Made of Poly(L- lactide) In Vitro and In Vivo
}

Løvdal, Alexandra Liv Vest; Calve, Sarah; Yang, Shuo; Van Alstine, William; Binkert, Christoph A; Klausen, Kasper

Published in:

Cardiovascular and Interventional Radiology

Link to article, DOI:

$10.1007 / \mathrm{s} 00270-016-1491-2$

Publication date:

2017

Document Version

Peer reviewed version

Link back to DTU Orbit

Citation $(A P A)$ :

Løvdal, A. L. V., Calve, S., Yang, S., Van Alstine, W., Binkert, C. A., \& Klausen, K. (2017). Evaluation of a Bioabsorbable Self-Expandable Vein Stent-Base Made of Poly ( -lactide) In Vitro and In Vivo. Cardiovascular and Interventional Radiology, 40(1), 112-119. https://doi.org/10.1007/s00270-016-1491-2

\section{General rights}

Copyright and moral rights for the publications made accessible in the public portal are retained by the authors and/or other copyright owners and it is a condition of accessing publications that users recognise and abide by the legal requirements associated with these rights.

- Users may download and print one copy of any publication from the public portal for the purpose of private study or research.

- You may not further distribute the material or use it for any profit-making activity or commercial gain

- You may freely distribute the URL identifying the publication in the public portal 


\section{Evaluation of a Bioabsorbable Self- Expandable Vein Stent-Base Made of Poly(L-lactide) In Vitro and In Vivo}

Alexandra Liv Vest Løvdal, $1{ }^{*}$

Emailalvlo@nanotech.dtu.dk

Sarah Calve, ${ }^{2}$

Shuo Yang, 3

William Van Alstine, ${ }^{3}$

Christoph A. Binkert, ${ }^{4}$

Kasper Klausen, 5

1 Department of Micro- and Nanotechnology, Technical University of

Denmark, Ørsteds Plads, 345E, 2800 Kongens Lyngby, Denmark

2 Weldon School of Biomedical Engineering, Purdue University, 206 S. Martin Jischke Drive, West Lafayette, IN, 47907-2032 USA

3 Cook Research Incorporated, 1 Geddes Way, West Lafayette, IN, 47906 USA

${ }^{4}$ Kantonsspital Winterthur, Institut für Radiologie, Brauerstrasse

15, Winterthur, 8401 Switzerland

5 William Cook Europe, Sandet 6, 4632 Bjæverskov, Denmark

\section{Abstract \\ Purpose}

This study was designed to evaluate performance and tissue response to a selfexpandable bioabsorbable vein stent-base cut from a tube with enhanced stiffness and strength in vitro and in vivo. 


\section{Methods}

A diamond-shaped stent-base was cut from a sequential biaxially strained poly(L-lactide) (PLLA) tube for optimized performance. The performance of the stent-base was evaluated in a finite element analysis model, and validation was attempted in vitro through a cyclic flat-plate compression and radial force measurement. The performance of the stent-base was tested in vivo using 3 sheep with 2 implants each for 2 and 31/2 weeks, respectively.

\section{Results}

In vitro the stent-base showed an elliptical deformation but no fractures. In vivo the stent-base showed adequate radial force and no migration. All implanted stent-bases showed multiple fractures not only at the predicted stress zones but at all connecting points. Fragments of the caudal stent-base stayed in the vein wall indicating sufficient tissue coverage to avoid embolization of the fractured stent pieces, whereas fragments from the cranial device remaining were few. Neointima formation was confirmed histologically at 2 and $3 \frac{1}{2}$ weeks.

\section{Conclusion}

A bioabsorbable self-expandable stent-base made from PLLA for large veins seems feasible, but over time, the PLLA used in this study appears too stiff and lacks the sufficient flexibility to move with the vena cava, causing multiple fractures.

\section{Keywords}

Self-expandable

Vein stent

Bioabsorbable

PLLA

Poly-(L-lactide)

\section{Introduction}

In the case of treatment of endovascular vein diseases or prophylactic indication, permanent metal devices such as stents or inferior vena cava (IVC) filters are being used. Regardless of indication, long-term complications exist with permanent vascular devices like vessel narrowing, perforation, migration, 
pulmonary embolism, and reoccurring deep vein thrombosis (DVT) [1, 2, 3] which can be avoided using a temporary bioabsorbable vascular device. There are numerous studies on the bioabsorbable vascular devices for arterial use, but not for venous applications. Previous work on bioabsorbable stents focused on balloon-expandable designs with an outer diameter (OD) of 3-10 mm $[4,5,6,7,8,9,10,11]$ for arterial indications and, therefore, is not applicable for large veins [12]. Within the available bioabsorbable polymers, poly-LLactide (PLLA) possesses some appropriate mechanical properties and degradation rate for vascular devices. It has been widely investigated in medical applications [13, 14]. They include arterial vascular devices such as the BVS vascular stent (Abbott Vascular, Santa Clara, CA) and the Igaki-Tamai stent (Igaki Medical Planning Company, Kyoto, Japan) [9, 15], but never as a selfexpandable stent or potential stent-base for an IVC filter. Placement of a vascular self-expanding stent-base, whether functioning as a stent or as a stentbase, requires an adequate radial force to maintain its position in the lumen with no migration and must have resistance to permanent deformation [4]. The bioabsorbable elastomer polycaprolactone has been tested in vivo in the IVC as a stent-base, but due to the low stiffness of PCL, the device migrated [16].

Polydioxanone has also been tested in the IVC, which exhibited good mechanical properties for 35 days without migration, but the device was not selfexpandable [17]. It is believed that PLLA can exhibit adequate properties and may therefore be a potential candidate for a vein stent or stent-base for an IVC filter. Stent-bases made from bioabsorbable polymers have inferior mechanical properties to those of metals and both radial force and resistance to a permanent deformation is low. PLLA can be induced with a greater stiffness, and provide greater resistance toward permanent deformation by straining the polymer above its glass transition temperature and thereby align its molecular chains $[18,19,20]$. The scope of this study was to evaluate the performance of a selfexpandable PLLA vein stent-base in vitro and in vivo.

\section{Materials and Methods}

\section{Stent-Base Material and Design}

A PLLA stent-base was made by sequential biaxially straining a hollow tube of PLLA 2003D (NatureWorks LLC, Minnetonka, MN) as previously described [21] and expanded from 5.5 to $10.5 \mathrm{~mm}$. The tube was laser cut in a diamondshaped pattern ( 8 cells circumferentially) (Fig. 1). The stent-base with the length of $50 \mathrm{~mm}$ was heat treated at $63{ }^{\circ} \mathrm{C}$ for 5 min after which it was further expanded over a preheated mandrill (OD $27 \mathrm{~mm}$ ) at $93{ }^{\circ} \mathrm{C}$ for $5 \mathrm{~min}$. The stentbases were sterilized with ethylene oxide at $53{ }^{\circ} \mathrm{C}$ and $75 \%$ humidity for $8 \mathrm{~h}$. To ensure visibility under X-ray, gold markers ( $1 \mathrm{~mm}$ in diameter) were sutured to 
each end of the stent-base. Through the above-mentioned processing, the stentbase becomes self-expandable. It is achieved as a combination of polymer chain orientation to improve stiffness and a tailored stent design, so that the stent-base does not undergo permanent deformation when loaded into the delivery sheath.

\section{Fig. 1}

\section{Lasercut PLLA stent}

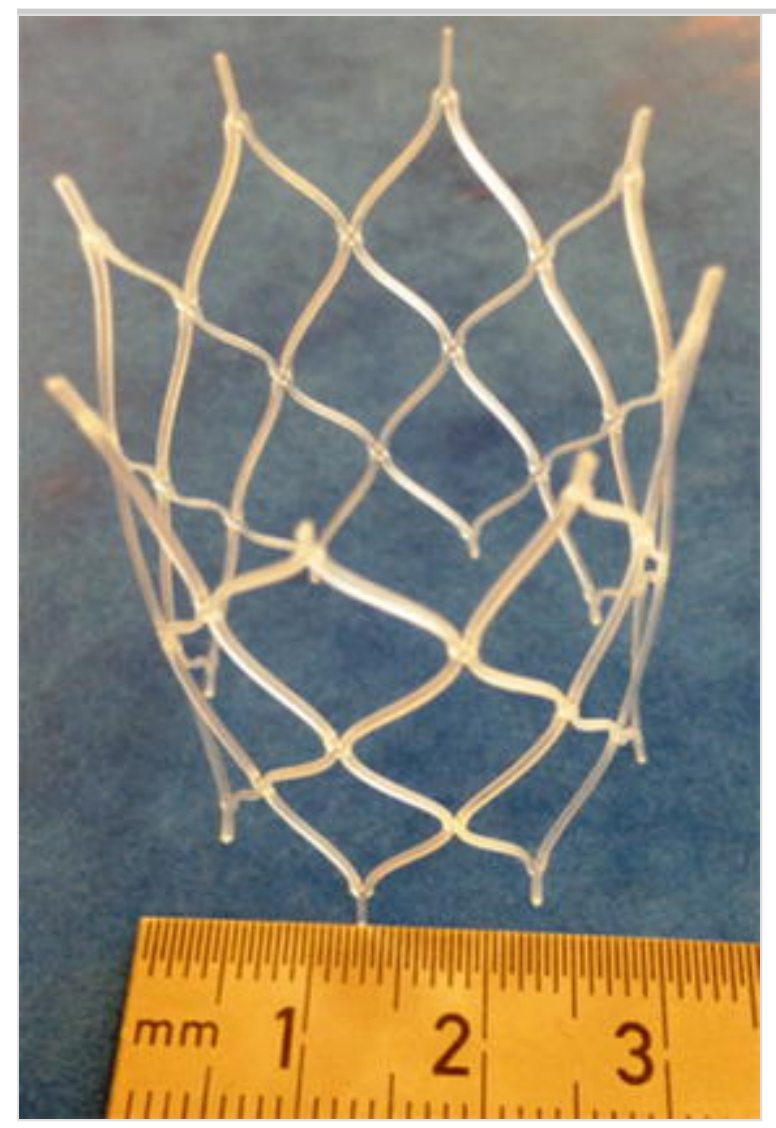

\section{Cyclic Compression and Radial Force}

Finite element analysis (FEA) was used to investigate stress distributions under a parallel flat-plate compression mimicking load from organs and the diaphragm on the IVC. Ultimate tensile stress (UTS) was set to $100 \mathrm{MPa}$ [22] and wall thickness to $0.8 \mathrm{~mm}$. Under normal conditions, the collapse index (CI) or compression degree on the IVC has been reported between 20 and 35\% [23]. CI is defined by the diameter upon expiration minus the minimal diameter on inspiration divided by the diameter on expiration. For the calculation, a cava diameter of $15.0 \mathrm{~mm}$ was assumed with a compression to $9.8 \mathrm{~mm}$, and CI was set to $35 \%$.

For in vitro testing, the stent was placed into a silicone tube (OD $19 \mathrm{~mm}$, $0.46 \mathrm{~mm}$ wall thickness) in water at $37^{\circ} \mathrm{C}$ and compressed (30\%) using a moving flat plate for 150,000 cycles, corresponding to $21,600-28,800$ breaths per day [24]. The radial force measurement was done in air at $37^{\circ} \mathrm{C}$ using an 
automated radial force tester from an expanded state to $6 \mathrm{~mm}$ at a rate of $0.5 \mathrm{~mm} / \mathrm{s}$ three times.

\section{Animal Study}

Three adult sheep (1-3 years of age) were used as the animal model. Intubation anesthesia was applied using isoflurane (1-5\%) $(1.5-2.5 \mathrm{~L} / \mathrm{min})$. A cut down on the jugular vein was used for access, and a $16 \mathrm{~F}$ sheath was introduced into which $100-300 \mathrm{IU} / \mathrm{kg}$ of heparin was administered. Upon loading the stent-base was crimped using a compression station, and the sheath was advanced over it, just prior to implantation. One stent-base above and one below the renal veins were implanted into the cava of each animal. Diameters of the cava were measured in right anterior (RAO) and left anterior (LAO) projection before and after stentbase implantation, respectively, and listed in Table 1. Accurate placement and vein patency were confirmed by venography. A representative venogram of the cranial and caudal stent-bases is shown in Fig. 2. Additional venography was performed 2 weeks after implantation.

Table 1

Diameter before loading into delivery sheath and after release from loading (step 1)

\begin{tabular}{|c|c|c|c|c|c|}
\hline $\begin{array}{l}\text { Compression } \\
\text { method }\end{array}$ & & $\begin{array}{l}\text { OD }(\mathrm{mm}) \\
\text { before }\end{array}$ & $\begin{array}{l}\text { Upon } \\
\text { release } \\
\text { OD }_{\text {top }}(\mathrm{mm})\end{array}$ & $\begin{array}{l}\text { Upon } \\
\text { release } \\
\text { OD }_{\text {side }}(\mathrm{mm})\end{array}$ & $\begin{array}{l}\text { Shape } \\
\text { after }\end{array}$ \\
\hline $\begin{array}{l}\text { Step } 1 \\
\text { Circumferential } \\
\text { crimping }\end{array}$ & $\begin{array}{l}\text { Delivery } \\
\text { sheath } \\
n=2\end{array}$ & $28.1 \pm 0.6$ & $24.6 \pm 0.4$ & $24.6 \pm 0.4$ & Circular \\
\hline $\begin{array}{l}\text { Step } 2 \text { Flat-plate } \\
\text { compression }\end{array}$ & $\begin{array}{l}\text { Wet at } \\
37^{\circ} \mathrm{C} \\
n=1\end{array}$ & 24.2 & 20.4 & 27.2 & Elliptical \\
\hline \multicolumn{6}{|c|}{$\begin{array}{l}\text { Diameter before loading into delivery sheath and after release from loading (Step 1). } \\
\text { Additionally diameter before stent base was delivered into a silicon tube and after } \\
\text { cyclic flat-plate compression under physiological conditions at } 37^{\circ} \mathrm{C} \text { (step } 2 \text { ). } \mathrm{n} \text { is the } \\
\text { number stent-bases tested. OD } \text { top }_{\text {is the distance from top to bottom which was in }} \\
\text { contact with the flat-plate, and } \mathrm{OD}_{\text {side }} \text { is the distance from one side to another not in } \\
\text { contact with the flat-plate }\end{array}$} \\
\hline
\end{tabular}

Fig. 2

Representative biplane venogram with contrast media in right (RAO) and left (LAO) anterior oblique view at post-implantation. The red circles indicate positions of the gold markers. The PLLA stent-bases are not visible 




At 1 and 2 weeks post-implant, interim radiography without contrast was performed to evaluate the stent-base position. One animal was sacrificed after 2 weeks and 2 animals after $3 \frac{1}{2}$ weeks. The cava was perfusion fixated using buffered $10 \%$ formalin solution before harvesting and examined with MRI to evaluate the integrity of the stent-bases. Tissue from lungs, spleen, and liver was investigated for residuals and fragments of the stent-bases.

\section{Tissue Examination}

Half of each explant with the stented vein was embedded in paraffin using routine techniques, cut at $5 \mu \mathrm{m}$, and stained with haematoxylin and eosin (H\&E). The other half was used for confocal imaging. The explanted tissue was cleared to ensure greater visibility by incubating the tissue in solutions of gradually increasing fructose concentration [25 ]. D-(-)-fructose (JT Baker, Center Valley, PA) was dissolved in milliQ water with $0.5 \% \alpha$-thioglycerol (Sigma-Aldrich St. Louis, MO) at various concentrations from 20 to $115 \% \mathrm{wt} / \mathrm{wt}$ as described previously [26] and incubated in each solution for 12-24 h under gentle rocking. 
For antibody staining, the fixed tissue was rinsed in phosphate buffered saline (PBS) blocked with $10 \%$ donkey serum in $0.2 \%$ bovine serum albumin (BSA) and permeabilized with $0.2 \%$ TritonX-100 overnight. Tissue was incubated with a primary antibody against fibrinogen (ab 119948 1:100, Abcam), diluted in $0.2 \% \mathrm{BSA}$ and PBS, for 2 days at $4{ }^{\circ} \mathrm{C}$ then rinsed $3 \times 30 \mathrm{~min}$. Samples were next stained with secondary labeling reagents for nuclei (DAPI, 1:500, LifeTechnologies), actin filaments (AF488 conjugated phalloidin 1:100, LifeTechnologies), and anti-mouse secondary antibody (AF555-conjugated 1:500, LifeTechnologies) for 2 days at $4{ }^{\circ} \mathrm{C}$, and then rinsed $3 \times 30 \mathrm{~min}$ and stored at $4{ }^{\circ} \mathrm{C}$ until imaged.

To increase the optical resolution and the contrast of the probe, a spatial pinhole was placed at the confocal plane of the lens to eliminate out-of-focus light. Tissue samples were imaged with an inverted confocal laser microscope (710 LMS, Zeiss, Germany) with laser wavelengths from 405 to $639 \mathrm{~nm}$. Images were obtained as $1024 \times 1024$ pixels with ZEN 2011 software and taken as a best compromise between overlaid laser wavelengths.

\section{Results}

\section{Radial Force and Fatigue Testing}

The radial force was highest after the first crimp and reduced slightly during the second and third crimps (Fig. 3). The stent-base in the physiological procedure would be crimped into the loading sheath (16F) and self-expand into the vessel of a given size. In the in vivo study, the average diameter was approximately $15-$ $16 \mathrm{~mm}$ and the stent-base would, therefore, exert a radial force of approx. $2.8 \mathrm{~N}$ on the vessel.

Fig. 3

Radial force measurement at $37{ }^{\circ} \mathrm{C}$ under dry condition. The stent-base was crimped from 30 to $6 \mathrm{~mm}$ at of $0.5 \mathrm{~s} / \mathrm{mm}$. $n$ is the number of stent-bases tested. The force is measured in newton $(\mathrm{N})$ 


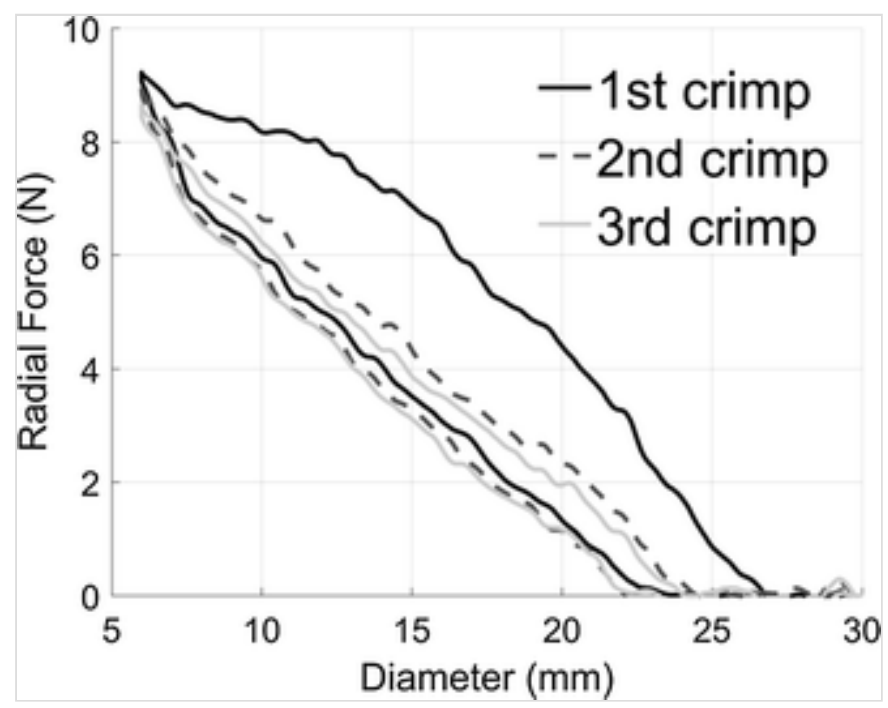

The fatigue performance of the stent-base was evaluated by a flat-plate crush analysis, both theoretically by finite element analysis (FEA) and in vitro. The FEA results (Fig. 4) show that the critical fatigue locations are found at the connection points on the side of the stent-base during compression. The critical fatigue locations in the red zone would be expected to fracture first, if physiological loading exceeds the capabilities of the newly-deployed stent. Neither crimping nor flat-plate compression in vitro demonstrated a fracture of the stent-base.

\section{Fig. 4}

Fatigue safety factor contour plot during a flat-plate compression of diamond shape stent design based on FEA. Red is the most stressed areas of the stent

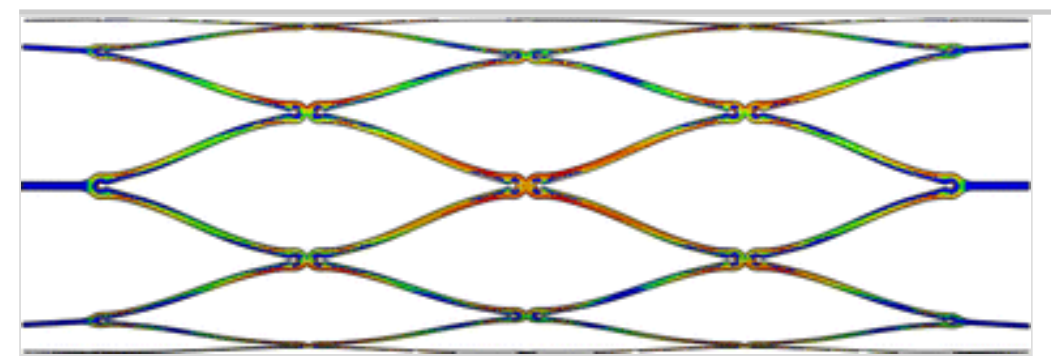

During crimping in the in vivo study, the stent-base was permanently deformed from 28 to $24 \mathrm{~mm}$ after being circumferentially compressed into a 16F sheath while maintaining its circular shape (Table 2). During cyclic compression in vitro, the stent-base deformed permanently from circular to elliptical. This is due to the fact that water or physiological fluids acts as a plasticizer and ultimately makes the polymer stent-base softer and more susceptible to a permanent set [27].

Table 2 
Placement and position, caval diameter pre- and post-implantation from right anterior (RAO) and left anterior (LAO) position

\begin{tabular}{|c|c|c|c|}
\hline Animal & Device & $\begin{array}{l}\text { Pre-diameter RAO/LAO } \\
(\mathrm{mm})\end{array}$ & $\begin{array}{l}\text { Post-diameter RAO/LAO } \\
(\mathrm{mm})\end{array}$ \\
\hline Annimikl & $\begin{array}{l}\text { Cranial } \\
\text { Device } \\
\text { Caudal }\end{array}$ & $\begin{array}{l}\text { 15.9/13.8 } \\
\text { Pre-diameter RAO/LAO } \\
\text { (1RAB) } 19.2\end{array}$ & $\begin{array}{l}\text { 17.3/18.0 } \\
\text { Post-diameter RAO/LAO } \\
\text { (1010) } 6.6\end{array}$ \\
\hline \multirow{2}{*}{$\begin{array}{l}3^{1 / 2} \text { week } \\
(1 \mathrm{st})\end{array}$} & Cranial & $16.8 / 12.5$ & $16.3 / 15.7$ \\
\hline & Caudal & $19.3 / 18.2$ & $17.9 / 18.3$ \\
\hline \multirow{2}{*}{$\begin{array}{l}31 / 2 \text { week } \\
(2 \mathrm{nd})\end{array}$} & Cranial & $14.6 / 15.4$ & $14.4 / 16.3$ \\
\hline & Caudal & $16.0 / 16.5$ & $16.1 / 19.1$ \\
\hline
\end{tabular}

\section{Imaging}

The gold markers were at the same location in all animals after implantation, at 1 week and after 2 weeks. The position of the gold markers confirmed a stable position of the stent-base without migration. Venography confirmed patency after 2 weeks ( 1 animal). The vena cava diameter was smaller than that before implantation and was likely due to different positioning of the animal and could not be used to determine the integrity of the device. MRI images of explants after 2 weeks illustrated numerous fractures which were visually confirmed by light microscopy. A representative section of the vein had 13 fractures (see Fig. $5 \mathrm{~A}$ ) after 2 weeks, and a similar section had 18 fractures (see Fig. 5B) after $3 \frac{1}{2}$ weeks. The fractures occurred at the connection points and between cells adherent to each other. The cranial devices at both time points were minimally intact, and only a few pieces remained at the site of implantation, whereas the fractured caudal devices remained in the vessel. Necropsy of lung tissue did not reveal end location of the migrated pieces.

\section{Fig. 5}

Representative light microscopy $(0.75 \times)$ of explanted caudal stent-bases and vein after 2 weeks and $3 \frac{1}{2}$ weeks including gold markers and blue suture. The box outside is zoomed in $(3.2 \times)$ 

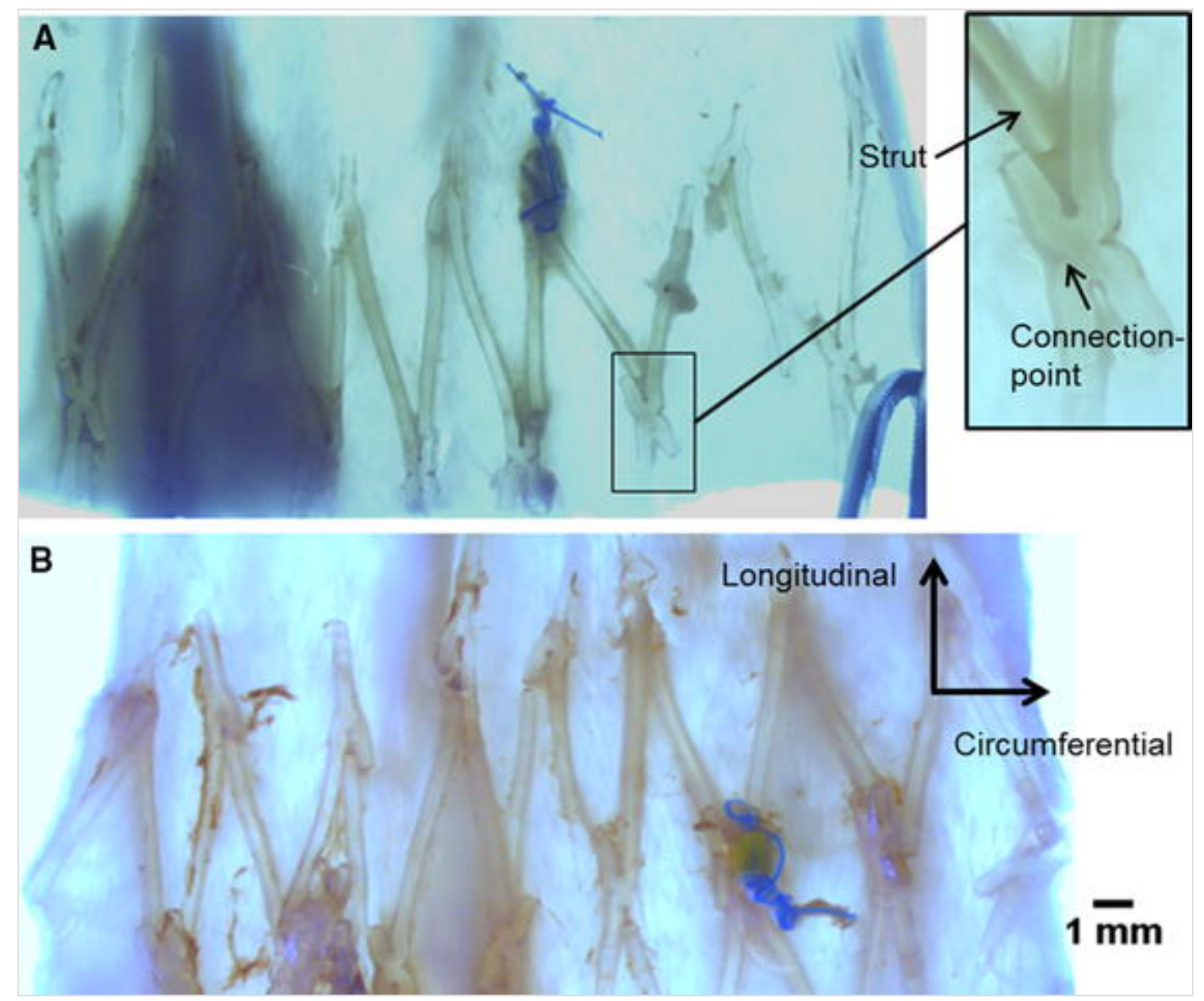

\section{Histology}

After 2 and $3 \frac{1}{2}$ weeks, the struts were closely apposed to the lumen surface and were covered by neointima with a thickness of 20-100 $\mu \mathrm{m}$ and $100-300 \mu \mathrm{m}$, respectively (Fig. 6). The neointima was composed of loosely arranged spindleshaped cells and fibrovascular tissue with some fibrin. At 2 weeks, some struts were covered with a single-cell layer of endothelium, and after $3 \frac{1}{2}$ weeks, most struts were covered with neointima and endothelium. At both time points, inflammation was minimal and composed of a few macrophages immediately adjacent the struts and few lymphocytes in the adjacent neointima. At the attachment sites between struts, vein wall smooth muscle cells were minimally vacuolated, suggesting mild focal pressure change.

\section{Fig. 6}

Representative images of H\&E stain of PLLA stent-base ( $S$ is the PLLA strut) in vena cava after 2 weeks. Struts are surrounded by loosely arranged fibrovascular tissue (neointima $\leftrightarrow$ ) that contained small amounts of fibrin and a few inflammatory cells (macrophages and lymphocytes). Furthermore the struts are partially covered by endothelium. Smooth muscle cells in the adjacent vena cava wall are minimally vascoulated 


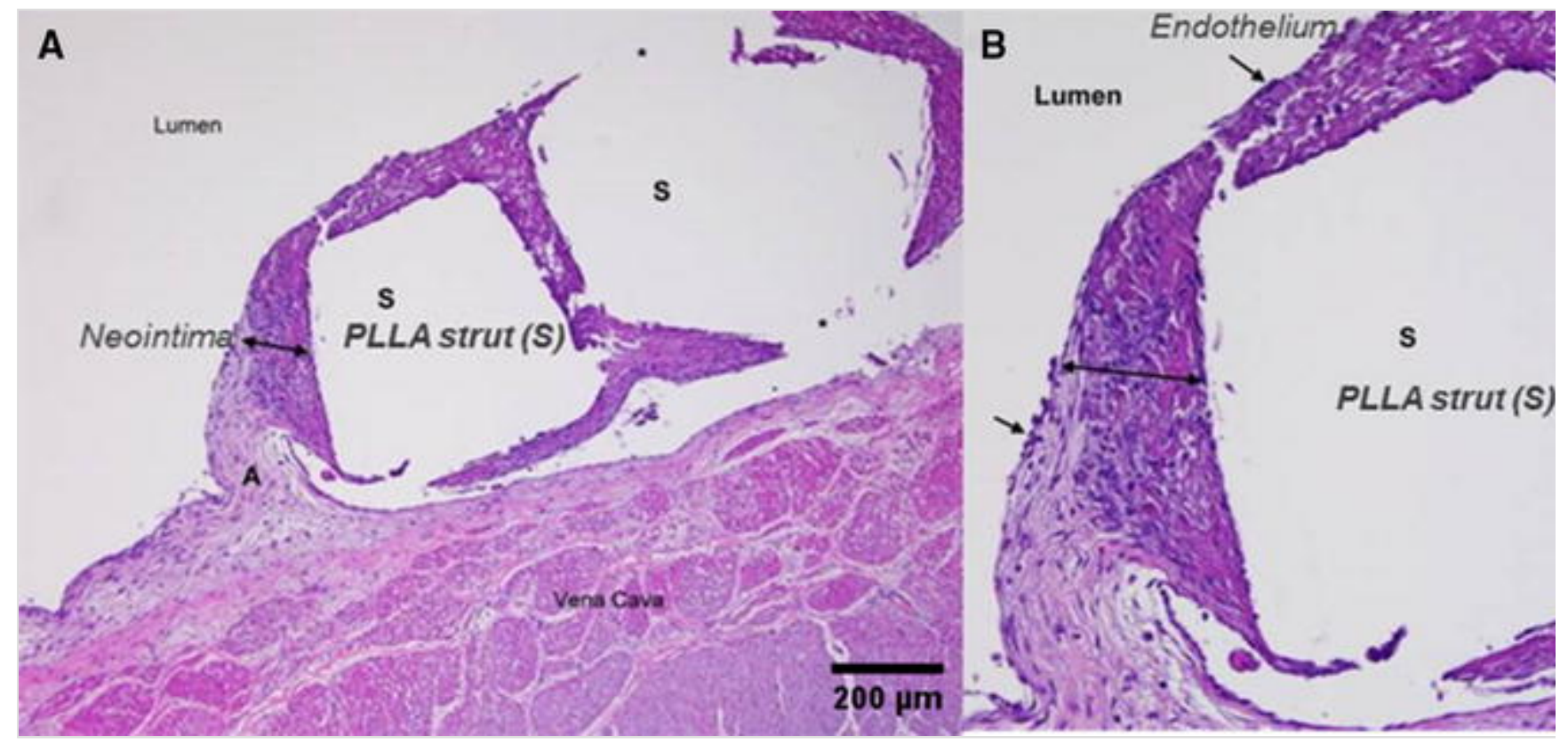

\section{Confocal Imaging}

Confocal imaging was used to visualize the newly formed tissue around the connection points without disrupting the tissue. It has the advantages of visualizing both the strut surface facing the lumen and the sides of the strut covered with neointima. The images showed cellular ingrowth around and in the connection points by either neointima nuclei (blue) or actin filament (green) (Fig. 7). Fibrinogen (red) covers both the struts in (Fig. 7 A, B) and connection points (Fig. 7C). The neointima around a strut that has fractured at the connection point measured between $70 \mu \mathrm{m}$ (top of the strut) and $120 \mu \mathrm{m}$ (on the right side) (Fig. 7A). The actin filaments occur only in the top cell layer (40$66 \mu \mathrm{m})$ on the sides and are aligned along the strut. At the fracture tip of the strut, the actin-filaments are randomly oriented.

\section{Fig. 7}

Representative confocal images of optically cleared specimens after $3 \frac{1}{2}$ weeks, where the normal vector to the plan (longitudinal-circumferential) is luminal. A, B show surface of a fractured strut. $\mathbf{C}$ show a connection point covered in nuclei and fibrinogen $(10 \times)$. Nuclei are represented by blue, actin-filaments by green and fibrinogen by red. The single headed arrows show sides with fewer nuclei at the corners of the strut. The double headed arrow show the neointima. The box shows the muscle/adventitial layer 

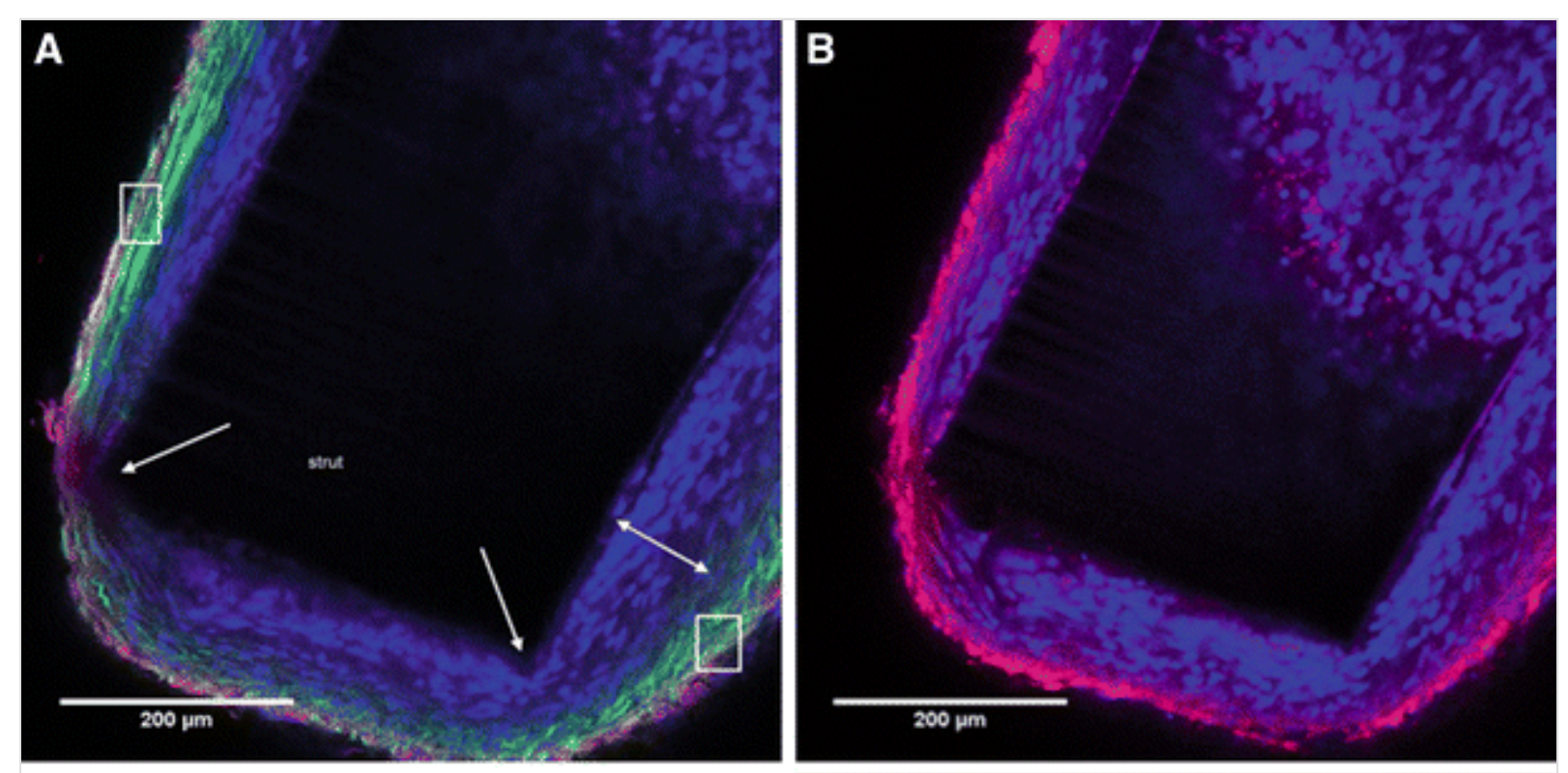

C
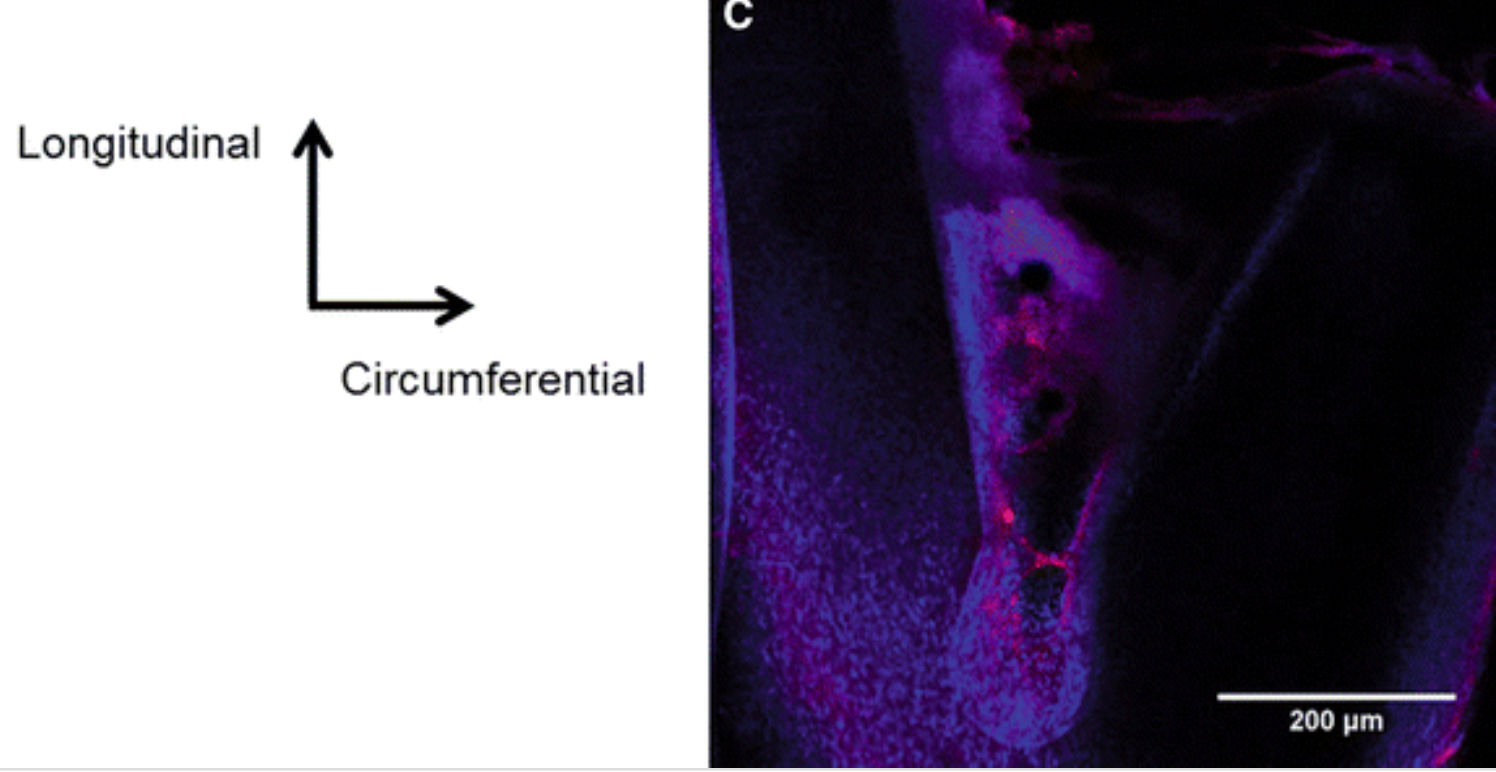

\section{Discussion}

One of the major concerns regarding a bioabsorbable polymeric device is the risk of migration and loss of integrity. It was hypothesized that a stent-base can be made from PLLA tubing, which had undergone a straining process. The stentbases were successfully crimped and delivered into the vena cava with no migration upon implantation or after $3 \frac{1}{2}$ weeks. The radial force of $2.8 \mathrm{~N}$ was adequate to prevent migration. The overall inflammation response to the PLLA stent-base was minimal. Both H\&E and confocal imagings showed fewer smooth muscle cells in the vein wall under the stent-base suggesting a mild focal fibrosis due to the oversized stent-base and resultant focal compression. In comparison, the Gianturco stainless steel stent (OD $24 \mathrm{~mm}$ and length $55 \mathrm{~mm}$ ), which has been used for treatment of superior vena cava syndrome [28], showed a radial force of approximately $2 \mathrm{~N}$ when crimped 37.5\% [29]. The compression degree was extrapolated to match the average size of the vena cava in this study. Therefore, it could be possible to place the PLLA stent-base in the vein for the 
same indications as the Gianturco stent. Furthermore, when placed in vena cavas with a $10 \%$ smaller diameter than the stent [30], the neointima growth was $200 \mu \mathrm{m}$ at week 4 and in the same range as what observed for the PLLA stentbase. The tissue response of an over-expanded vein to the PLLA stent-base is similar to one of stainless steels, despite the larger degree of over-expansion in this study.

Both caudal and cranial stent-bases fractured to the same degree in all three animals, but little remained of the cranial devices. Their end location was not revealed through necropsy indicating that the pieces were too small to detect. It is believed that the caudal stent-base was not exposed to the same degree of stress or that tissue coverage occurred faster over the caudal device before fractures occurred. Necropsy showed that above the renals, the liver and other viscera were more compacted into the cranial abdomen, and along with diaphragm movements, the cranial device was exposed to compression from multiple sides.

Although in vitro tests did not visually reveal any fracture of the stent-base, MRI and light microscopy confirmed that multiple fractures occurred at those sites where FEA was predicted to be critical. With fractures, the stent-base lost its integrity and would not be as stressed in the same manner, and no additional fractures were expected. The stent-base continued to fracture circumferentially at every connection point. The fragments of the caudal device did not migrate, and fractures likely occurred after tissue coverage adequately covered the stentbase.

PLLA is a brittle polymer and this particular stent-base is not flexible enough to move with the vena when the connection points are covered in tissue, leading to multiple device fractures. For a stent-base to successfully survive cyclic compression, it would have to be made more flexible, but still induce enough radial force to avoid migration. If the stent-base should function as a stent-base in an IVC filter, the filtration cone could either be done by applying bioabsorbable connected sutures to the top of the stent-base as done by Zhang et al. [16] or they could be laser-cut to extend from the stent-base.

\section{Conclusion}

Bioabsorbable self-expandable stent-bases made from PLLA tube were successfully delivered in an ovine vena cava. The tissue response and radial force were found adequate to prevent device migration. After two weeks, the explants had multiple circumferential fractures in the specific locations predicted by the FEA. The tissue response did not cause vessel narrowing and was 
sufficient to lock the stent in place. This particular PLLA stent-base did not have the flexibility to move with the vessel after tissue coverage. The locked circumferential stent-base cells fractured, resulting in stent-base failure.

\section{Acknowledgement}

The authors thank the Non-clinical Testing Team at Cook Research Incorporated for conducting the animal study.

Funding This study was funded by Innovation Fund Denmark.

Compliance with Ethical Standards

Conflict of interest Studied sponsored by William Cook Europe as a part of the Industrial PhD Program.

Ethical approval All applicable international, national, and/or institutional guidelines for the care and use of animals were followed.

\section{References}

1. Nagata T, Makutani S, Uchida H, Kichikawa K, Maeda M, Yoshioka T, Anai H, Sakaguchi H, Yoshimura H. Follow-up results of 71 patients undergoing metallic stent placement for the treatment of a malignant obstruction of the superior vena cava. Cardiovasc Intervent Radiol. 2007;30:959-67.

2. Imberti D, Ageno W, Dentali F, Donadini M, Mandredini R, Gallerani M. Retrievable vena cava filters: a clinical review. J Thromb Thrombolysis. 2012;33:258-66.

3. Rizvi AZ, Kalra M, Bjarnason H, Bower TC, Schleck C, Gloviczi P. Benign superior vena cava syndrome: stenting is now the first line of treatment. J Vasc Surg. 2008;47:372-80.

4. Nuutinen J, Clerc C, Törmälä P. Mechanical properties and in vitro degradation of bioabsorbable self-expanding braided stents. J Biomater Sci Polymer Edn. 2003;14:667-87.

5. Hayman D, Bergsson C, Miller S, Moreno M, Moore JE. The effect of static and dynamic loading on degradation of PLLA stent fibers. J Biomech Eng. 2014;136:1-9. 
6. Welch TR, Eberhart RC, Reisch J, Chuong C. Influence of thermal annealing on the mechanical properties of PLLA coiled stents. Cardiovasc Eng Technol. 2014;5:270-80.

7. Vaazjanen A, Nuutinen J, Isotalo T, Törmälä P, Tammela TLJ, Talja M. Expansion and fixation properties of a new braided bioabsorbable urethral stent: an experimental study in the rabbit. J Urol. 2003;169:1171-4.

8. Wu Y, Shen L, Wang Q, Ge L, Xie J, Hu X, Sun A, Qian J. Comparison of acute recoil between bioabsorbable poly-L-lactic acid XINSORB stent and metallic stent in porcine model. J Biomed Biotechnol. 2012;13:1-8.

9. Ormiston JA, Serruys PW. Bioabsorbable coronary stents. Circ Cardiovasc Intervent. 2009;2:255-60.

10. Ginsberg G, Shah J, Carty A, Kaufmann C, Nuutinen J, Törmäla P. In vivo evaluation of a new bioabsorbable self-expanding biliary stent. Gastrointest Endosc. 2003;58:777-84.

11. Mario CD, Borgia F. Assimilating the current clinical data of fully bioabsorbable stents. EuroIntervention Suppl. 2009;5:103-8.

12. Thomas SD, Ofri A, Tang T, Englund R. Endovascular reconstruction of an interrupted inferior vena cava. Int J Surg Case Rep. 2014;5:59-62.

13. Lasprilla AJR, Martinez GAR, Lunelli BH, Jardini AL, Filho RM. Polylactic acid synthesis for application in biomedical devices-a review. Biotechnol Adv. 2012;30:321-8.

14. Nair LS, Laurencin CT. Biodegradable polymers as biomaterials. Prog Polym Sci. 2007;32:762-98.

15. Van Ditzhuijzen NS, Karanosos A, Van der Sijde JN, Van Soest G, Regar E. Bioabsorbable stent. In: Jang I, editor. Cardiovascular OCT imaging. Dordrecht: Springer; 2015. p. 179-93.

16. Zhang F, Hailei L, Liang G, Zhang H. Development and evaluation of a new biodegradable vena cava filter in a canine model. Asian J Surg. 2015; xx: $1-5$.

17. Eggers MD, McArthurt MJ, Figueira TA, Abdelsalam ME, Dixon KP, Pageon LR, Wallace MJ, Huang SY. Pilot in vivo study of an absorbable 
polydioxanone vena cava filter. J Vasc Surg. 2015;3:409-20.

18. Ou X, Cakmak M. Comparative study on development of structural hierarchy in constrained annealed simultaneous and sequential biaxially stretched polylactic acid films. Polymer. 2010;51:783-92.

19. Tsai C, Wu R, Cheng H, Li S, Siao Y, Kong D, Jang G. Crystallinity and dimensional stability of biaxial oriented poly(lactic acid) films. Polym Degrad Stab. 2010;95:1292-8.

20. Wu J, Yen M, Wu C, Li C, Kuo MC. Effect of biaxial stretching on thermal properties, shrinkage and mechanical properties of poly (lactic acid) films. J Polym Environ. 2013;21:303-11.

21. Løvdal A, Andreasen JW, Mikkelsen LP, Agersted K, Almdal K. Characterization of biaxial strain of poly(L-lactide) tubes. Polym Int. 2016;65:133-41.

22. Lingaiah K. Machine design data handbook. New York: McGraw-Hill; 1994.

23. Wallace DJ, Allision M, Stone MB. Inferior vena cava percentage collapse during respiration is affected by the sampling location: an ultrasound study in healthy volunteers. Acad Emergy Med. 2010;17:96-9.

24. Maddox S. Measuring vital in signs. In: Baillie L, editor. Developing practical adult nursing skills. Fargo: CRC Press Taylor \& Francis; 2009. p. $116-518$.

25. Ke MT, Fujimoto S, Imai T. SeeDB: a simple and morphology-preserving optical clearing agent for neuronal circuit reconstruction. Nat Neurosci. 2013;16:1154-61.

26. Calve S, Ready A, Huppenbauer C, Main R, Neu CP. Optical clearing in dense connective tissues to visualize cellular connectivity in situ. PLoS ONE. 2015;10:1-14.

27. Vieira AC, Guedes RM, Tita V. Considerations for the design of polymeric biodegradable products. J Polym Eng. 2013;33:292-302.

28. Irving JD, Dondelinger RF, Reidy JF, Schild H, Dick R, Adam A, Maynar M, Zollikofer CL. Gianturco serf-expanding stents: clinical 
experience in the vena cava and large veins. Cardiovasc Intervent Radiol. 1992;15:328-33.

29. Johnston CR, Lee K, Flewitt J, Moore R, Dobson GM, Thornton GM. The mechanical properties of endovascular stents: an in vitro assessment. Cardiovasc Eng. 2010;10:128-35.

30. Miyazaki K, Nishibe T, Manase H, Ohkashiwa H, Takahashi T, Watanabe S, Katoh H, Morita Y. Gianturco stents for the venous system: a detailed pathological study. Jpn J Surg. 1998;28:396-400. 